\title{
Metal content of surface soils in parks and allotments from three European cities: initial pilot study results
}

Andrew Hursthouse, Donna Tognarelli, Peter Tucker, Franco Ajmone Marsan, Chiara Martini, Luis Madrid, Fernando Madrid and Encarnacion DiazBarrientos

\begin{abstract}
A pilot study of metal content and basic soil properties was undertaken in a number of parks and allotments in the cities of Glasgow, UK, Torino, Italy, and Sevilla, Spain.

Between 40 and 60 samples were collected from each city, with soil from two depths. The maximum metal contents (aqua regia) found were $698 \mathrm{mg} / \mathrm{kg} \mathrm{Cu;} 1004 \mathrm{mg} / \mathrm{kg} \mathrm{Zn;}$ $300 \mathrm{mg} / \mathrm{kg} \mathrm{Ni} ; 356 \mathrm{mg} / \mathrm{kg} \mathrm{Cr}$ and $7051 \mathrm{mg} / \mathrm{kg} \mathrm{Pb}$. Variability of metal content showed similar patterns across all cities, with a number of outlier data points. Surface and subsurface samples were comparable within sites. $\mathrm{Cu}, \mathrm{Zn}$ and $\mathrm{Pb}$ levels appeared to contain most variability and extreme data points, while Ni and $\mathrm{Cr}$ were more homogeneous. The data support previously published observations of anthropogenic association ( $\mathrm{Cu}$, $\mathrm{Zn}$ and $\mathrm{Pb}$ ) and natural sources (Ni and $\mathrm{Cr}$ ), found in urban environments influenced by diffuse pollution. Within the Glasgow data, differences in the variability of metal content in park and allotment soil are not dramatic, but do reflect the influence of different agronomic activities. The study has provided baseline information for ongoing pan-European urban soil research funded through the EU.
\end{abstract}

Key words: urban soils; variability; metal pollution; parks; allotments

\section{INTRODUCTION AND BACKGROUND}

Concentrations of metallic elements in terrestrial environments have increased significantly as a result of human activities such as emissions from industrial plants and thermal power stations, waste disposal, soil amendments and vehicle traffic/road infrastructures. Low levels of many metals can pose significant health

Received March 2004; accepted June 2004

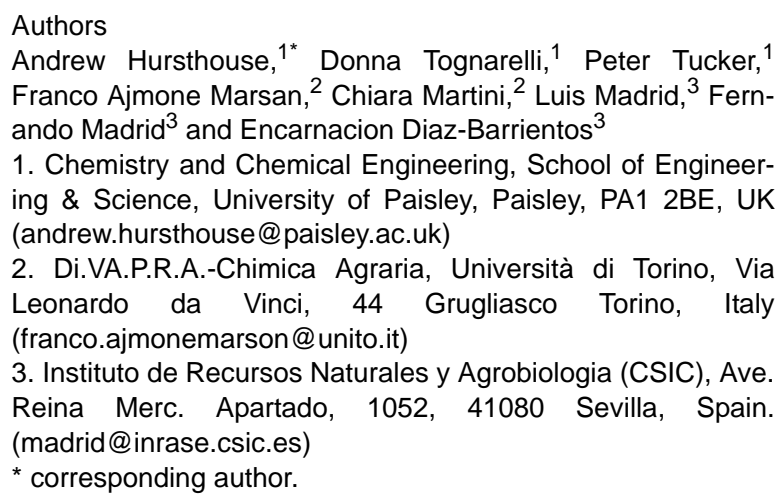

risks. Metallic pollutants which reach the soil remain present in the pedosphere for many years, even after the removal of pollution sources (Chen et al. 1997; Pichtel et al. 1997; Imperato et al. 2003). To evaluate the significance of often diffuse sources on urban soils, a major pan-European study is under way. A summary of initial findings from the reconnaissance survey are presented in this paper.

In urban areas, soils acquire new functions and play a distinct environmental role. They have aesthetic and recreational functions in parks and gardens, and contribute to the preservation of biodiversity. They directly influence public health: soil material in an urban environment can more easily come into contact with humans and be transferred through the metabolic chain either as resuspended dust or by direct contact (Bullock and Gregory 1991; Ferguson 1999).

While being rarely subject to ordinary agronomic operations, urban soil receives higher than normal loads of contaminants from traffic, industrial activities and waste disposal. The urban soil matrix is often subject to frequent disturbance, through engineering activities and changes in land use, which often end up with exten- 
Table 1. Comparison of cities

\begin{tabular}{|l|c|c|c|c|c|c|}
\hline City & Population & $\begin{array}{c}\text { Main pollution } \\
\text { sources }\end{array}$ & $\begin{array}{c}\text { Mean annual } \\
\text { temperature } \\
\left({ }^{\circ} \mathbf{C}\right)\end{array}$ & $\begin{array}{c}\text { Mean annual } \\
\text { precipitation } \\
(\mathbf{m m})\end{array}$ & $\begin{array}{c}\text { Geological } \\
\text { substrate }\end{array}$ & $\begin{array}{c}\text { Green areas - } \\
\text { extension (ha) }\end{array}$ \\
\hline Torino & 900000 & Industry/traffic & 12.6 & 750 & Alluvial & 125 \\
\hline Sevilla & 706000 & Traffic & 18.2 & 540 & Basaltic/alluvial & 273 \\
\hline Glasgow & 620000 & Industry/traffic & 8.9 & 991 & Alluvial & 3870 \\
\hline
\end{tabular}

sive sealing, which alters its relationship with water fluxes. Its substrate can be mixed with other anthropogenic materials that may modify its functioning.

There is a need for a better understanding of the quality and function of urban soils. Some limited work has been undertaken (Effland and Pouyat 1997; Pickett et al. 1997, 2001; Jim 1998) and, increasingly, urban geochemistry is identified as a focus of research into the impact of metallic contamination (Paterson et al. 1996; Kelly et al. 1996; Birke and Rauch 2000; Peltola and Astrom 2003). Whilst these considerable data-sets on chemical contamination add to the description, little regard has been given to soil function as a medium for plant growth, its role in the urban ecosystem and particularly its response to changes in external climatic variables or management conditions. As the debate relating to sustainable urban management and demonstration of appropriate sustainability indicators has evolved, very little consideration has been given to the position of soil and its properties, beyond obvious potential hazard to health, from contaminated sites. Ultimately, the soil system supports and sustains urban development, but we have very little information on its role and significance, and until recently it has been ignored in policy development (Lyons 1997; Pacione 2003; Van Kamp et al. 2003).

In an attempt to provide a harmonised approach to urban soil quality, the URBSOIL (http://urbsoil.paisley.ac.uk) project was established through EU FP5 Energy, Environment and Sustainable Development -
City of Tomorrow and Cultural Heritage (EVK4-CT2001-00053). The aim was to focus on urban soils as sources and sinks of pollution, within a common assessment framework, developing decision support systems for sustainable soil management.

As a pilot study to the main URBSOIL project, three cities were selected, which offered a wide range in climate, geology, population, and sources of pollution. The aims of the study were to:

1. survey soil quality and, in a limited number of public parks and gardens as indicated by basic soil properties and using the content of selected metals, to indicate the extent of anthropogenic influence;

2. assess the variability of survey methods and approaches from different cities;

3. evaluate sampling context and site variability in urban soil evaluation;

4. establish general soil properties and description methods for publicly managed land.

This paper reports initial findings from the pilot study, providing a limited soil quality data-set collected from parallel sampling campaigns in three regionally significant historical urban centres: Glasgow, UK, Torino, Italy and Sevilla, Spain. The cities vary in their historical development and regional setting. This can be seen from the wide range of climatic and general conditions, summarised in Table 1.

Table 2. Soil samples collected and sampling methodology used for each city

\begin{tabular}{|c|c|c|c|}
\hline City & No. of locations & No. of sampling points & Collection method \\
\hline Sevilla & $\begin{array}{l}5 \text { parks and formal } \\
\text { gardens, } 1 \text { private garden }\end{array}$ & $1-9$ & $\begin{array}{l}\text { Excavation using steel spade to collect from two depths } \\
\qquad(0-10,10-20 \mathrm{~cm})\end{array}$ \\
\hline Torino & $\begin{array}{l}8 \text { parks and formal } \\
\text { gardens }\end{array}$ & 12 & $\begin{array}{l}\text { Excavation using steel spade, } 3 \text { composite samples } \\
\text { from } 4 \text { pits at } 2 \text { depths }(0-10,10-20 \mathrm{~cm})\end{array}$ \\
\hline Glasgow & $\begin{array}{l}4 \text { parks } \\
4 \text { allotments }\end{array}$ & 10 & $\begin{array}{c}\text { Steel coring device, samples taken } 2-3 \mathrm{~m} \text { from } \\
\text { boundary fence, } 10 \text { cores collected from within a } 1 \mathrm{~m}^{2} \\
\text { zone; divided into two depths }(0-5,5-10 \mathrm{~cm}) \\
\text { Steel coring device, } 10 \text { cores collected randomly } \\
\text { across site; divided into two depths }\end{array}$ \\
\hline
\end{tabular}




\section{MATERIALS AND METHODS}

Soil samples were collected from a restricted number of parks, gardens and allotments in the three cities, over a one-year period. Sampling locations were chosen in consultation with the local municipality in each city, to reflect old parkland areas and gardens, which had been subject to continued use over long periods of time. Details of sample collection strategy are provided in Table 2. In two cities (Sevilla and Torino), composite samples were obtained by hand from the locations and, in Glasgow, a standard soil-coring device was used to collect ten replicate samples from a fixed area in four parks and randomly within four allotment gardens (managed by the city authorities).

In all cases, samples were air-dried and gently crushed to pass through a $2 \mathrm{~mm}$ sieve, and large stones were removed. The samples were characterised using standard methods for basic soil quality parameters: $\mathrm{pH}$, $\mathrm{CEC}$, organic matter, $\mathrm{C} / \mathrm{N}, \mathrm{P}, \mathrm{K}$, and particle size distribution (Page et al. 1982; Gee and Bauder 1986; HMSO 1986; Rowell 1994; Madrid et al. 2002), and screened for metal content using an aqua regia extract (e.g. Madrid et al. 2002). Analysis of metal content was in triplicate, using ICP-OES and flame AAS, with appropriate external standards. The limited amount of sample material collected restricted the analysis of some properties, particularly in the case of the Glasgow soil samples.

\section{RESULTS AND DISCUSSION}

Results for basic soil quality parameters are presented in Table 3, and the soil textural data are shown graphically in Figure 1. Generally, there is quite a variation in the basic soil properties across all data-sets. The soils of Sevilla and Torino are neutral to alkaline, in line with the calcareous nature of the parent material of local soils. Those from Glasgow tend to show lower $\mathrm{pH}$ and have slightly more organic matter, as might be expected from the temperate climate experienced in NW Europe. The soil textures for samples from Torino and Glasgow fall into the 'sand-loamy sand-sandy loam' region of the USDA classification. Those from Sevilla have a wider textural spread, showing the presence of a significantly higher silt/clay fraction. Where available, data for nutrients are quite variable, reflecting different management conditions, addition (or not) of fertilisers, and related soil properties (e.g. CEC). In all cases, the difference between surface and sub-surface samples was not significant for these parameters. It is difficult to comment on comparisons of these values with 'expected' conditions, agricultural standards

Table 3. Summary of basic soil properties

\begin{tabular}{|c|c|c|c|c|c|c|c|c|c|c|c|c|c|}
\hline & $\underset{\left(\mathrm{H}_{2} \mathrm{O}\right)}{\mathbf{p H}}$ & $\underset{(\mathrm{KCl})}{\mathrm{pH}}$ & $\begin{array}{c}\text { CCE }^{*} \\
\%\end{array}$ & $\begin{array}{c}\text { Organic } \\
\text { C } \\
\%\end{array}$ & $\begin{array}{c}\text { Total } \\
\mathbf{N} \\
\%\end{array}$ & $\mathrm{C} / \mathrm{N}$ & $\begin{array}{c}\mathbf{P} \\
\text { (Olsen) } \\
\mathrm{mg} / \mathrm{kg}\end{array}$ & $\begin{array}{c}\mathbf{K} \\
\text { (exch.) } \\
\mathrm{mg} / \mathrm{kg}\end{array}$ & $\mathrm{cmol}_{(\mathrm{c})}$ & $\begin{array}{c}\text { Coarse } \\
\text { sand }\end{array}$ & $\begin{array}{l}\text { Fine } \\
\text { sand }\end{array}$ & Silt & $\%$ \\
\hline \multicolumn{14}{|l|}{ Sevilla } \\
\hline mean & 7.6 & & 21 & 1.9 & 0.19 & 11 & 73 & 318 & & 25 & 12 & 37 & 25 \\
\hline RSD (\%) & 3 & & 30 & 62 & 72 & 25 & 165 & 48 & & 60 & 67 & 27 & 32 \\
\hline $\max$ & 8.0 & & 35 & 5.5 & 0.73 & 18 & 550 & 774 & & 54 & 34 & 58 & 44 \\
\hline $\min$ & 7.3 & & 3 & 0.23 & 0.03 & 3 & 1 & 109 & & 1 & 1 & 15 & 10 \\
\hline$n$ & 62 & & 62 & 62 & 62 & 62 & 62 & 62 & & 62 & 62 & 62 & 62 \\
\hline \multicolumn{14}{|l|}{ Torino } \\
\hline mean & 8.1 & 7.4 & 4.8 & 1.77 & 0.25 & 9 & 20.2 & 67 & 11.8 & 25 & 42 & 28 & 6 \\
\hline CV & 4 & 4 & 74 & 49 & 26 & 23 & 128 & 98 & 35 & 14 & 20 & 28 & 30 \\
\hline $\max$ & 8.6 & 7.9 & 14.0 & 3.8 & 0.4 & 13 & 107 & 330 & 19.9 & 34 & 55 & 40 & 10 \\
\hline $\min$ & 7.4 & 6.7 & 1.1 & 0.5 & 0.1 & 7 & 1.5 & 20 & 3.3 & 19 & 28 & 16 & 3 \\
\hline $\mathrm{n}$ & 40 & 40 & 40 & 40 & 16 & 16 & 40 & 40 & 40 & 40 & 40 & 40 & 40 \\
\hline \multicolumn{14}{|l|}{ Glasgow } \\
\hline mean & 5.6 & 5.3 & absent & 3.2 & & & & & 17 & 36 & 37 & 22 & 4 \\
\hline RSD (\%) & 11 & 15 & - & 27 & & & & & 27 & 20 & 13 & 25 & 41 \\
\hline $\max$ & 7.0 & 6.7 & - & 5.6 & & & & & 30 & 45 & 44 & 29 & 6 \\
\hline $\min$ & 4.3 & 4.0 & - & 1.7 & & & & & 6 & 24 & 29 & 14 & 1 \\
\hline $\mathrm{n}$ & 80 & 32 & - & 32 & & & & & 43 & 8 & 8 & 8 & 8 \\
\hline
\end{tabular}

${ }^{*} \mathrm{CCE}$ : Calcium carbonate equivalent; CEC: cation exchange capacity 

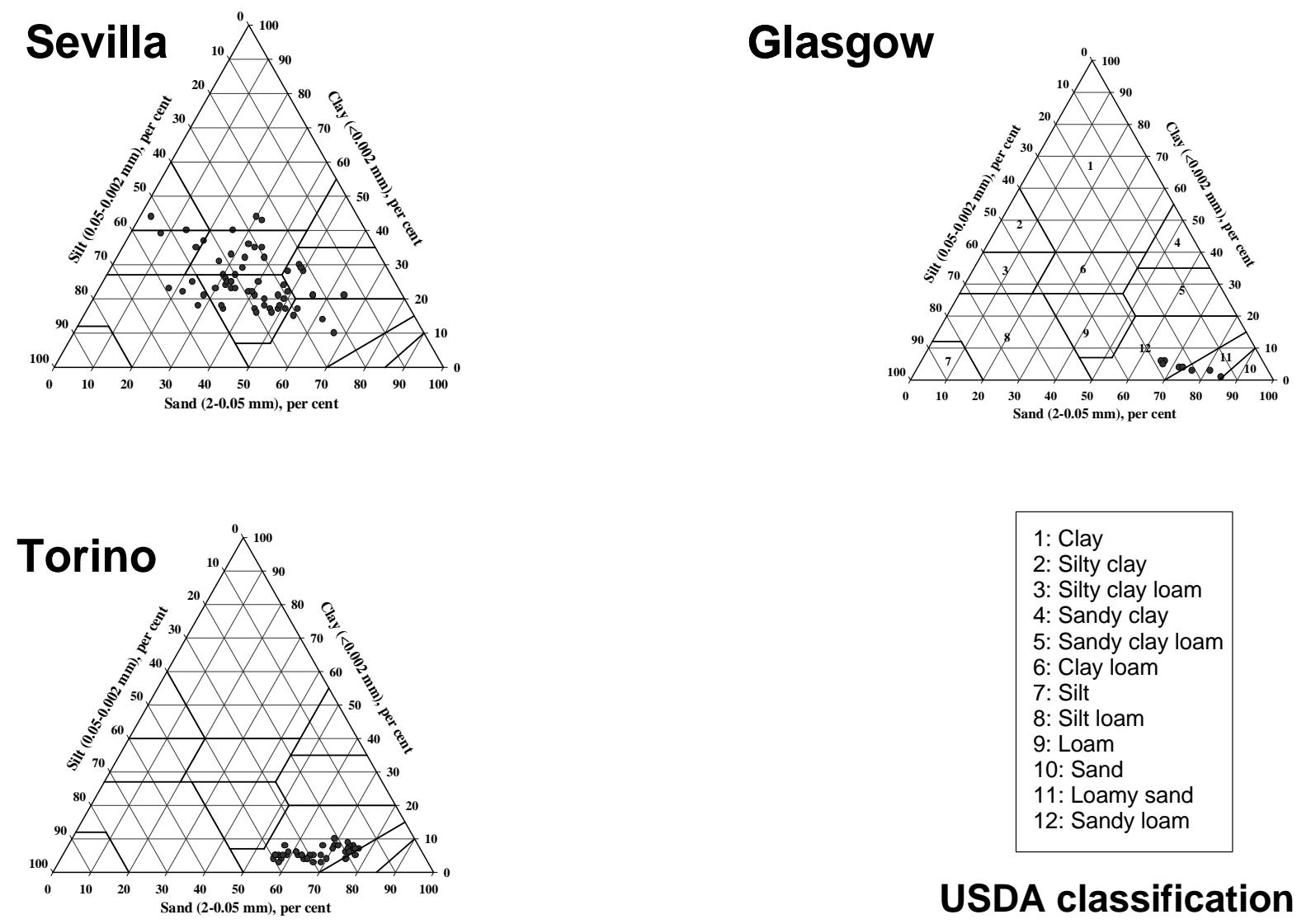

1: Clay
2: Silty clay
3: Silty clay loam
4: Sandy clay
5: Sandy clay loam
6: Clay loam
7: Silt
8: Silt loam
9: Loam
10: Sand
11: Loamy sand
12: Sandy loam

USDA classification

FIGURE 1. SOIL TEXTURE OF PARK AND GARDEN SAMPLES COLLECTED FROM SEVILLA, TORINO AND GLASGOW

and previous studies, as very little information exists for urban system soil quality (Jim 1998; Pickett et al. 2001).

Data for the metal content of soil samples are summarised in Table 4. The values show extremely wide variations for $\mathrm{Cu}, \mathrm{Zn}, \mathrm{Ni}, \mathrm{Cr}$ and $\mathrm{Pb}$, with extreme outliers for many elements found for all cities. This is most dramatic in the case of $\mathrm{Pb}$ in Glasgow and Sevilla, and, for Torino, relatively high levels of $\mathrm{Ni}$ and $\mathrm{Cr}$. The variability is not so high in the case of these elements in samples from Torino, and reflects the contribution of basic/ultrabasic Alpine geology in the region to the soil parent material (Facchinelli et al. 2001).

Comparison to what might be expected from an urban soil is supported by numerous examples in the literature. The study by Manta et al. (2002) tabulated mean values from a number of published studies of metals in 'urban soils' world-wide. At a superficial level, the mean data from the three cities in the pilot study fall within a range comparable to levels found elsewhere.

In the cases of Torino and Glasgow, more detailed studies of regional metal levels and variability have been published and are worth commenting on.

For Torino, the range of values (maximum-minimum) observed for $\mathrm{Cu}, \mathrm{Ni}$ and $\mathrm{Cr}$ is close to that for agricultural soils in the region (Facchinelli et al. 2001), reflecting the dominance of the natural contribution to $\mathrm{Ni}$ and $\mathrm{Cr}$. The situation for $\mathrm{Cu}$ is different, and reflects its widespread historical use in agriculture as a pesticide, applied within cities as well as in truly agricultural zones. In the case of $\mathrm{Zn}$ and $\mathrm{Pb}$, levels (range, mean) within the urban environment are significantly higher than those found in the wider district, indicating much stronger anthropogenic impacts.

A recent compilation of background levels in Scottish soils (Paterson et al. 2003) reviewed soil database information for metal content of mineral soils and a 


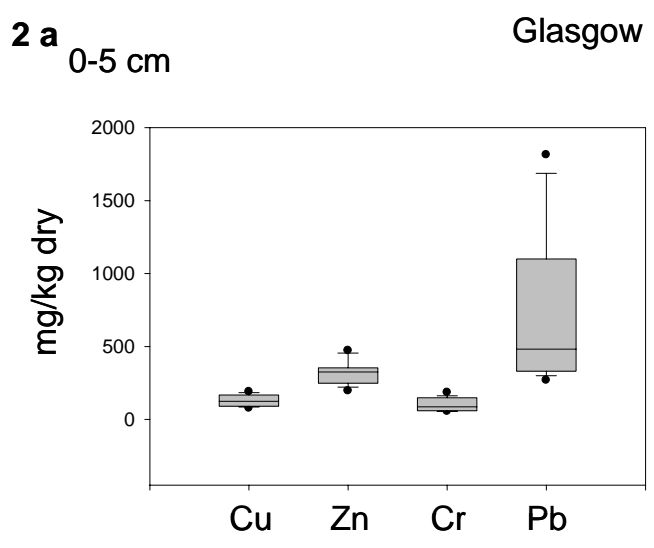

$2 \mathbf{b}_{0-5 \mathrm{~cm}}$

Glasgow - Allotments
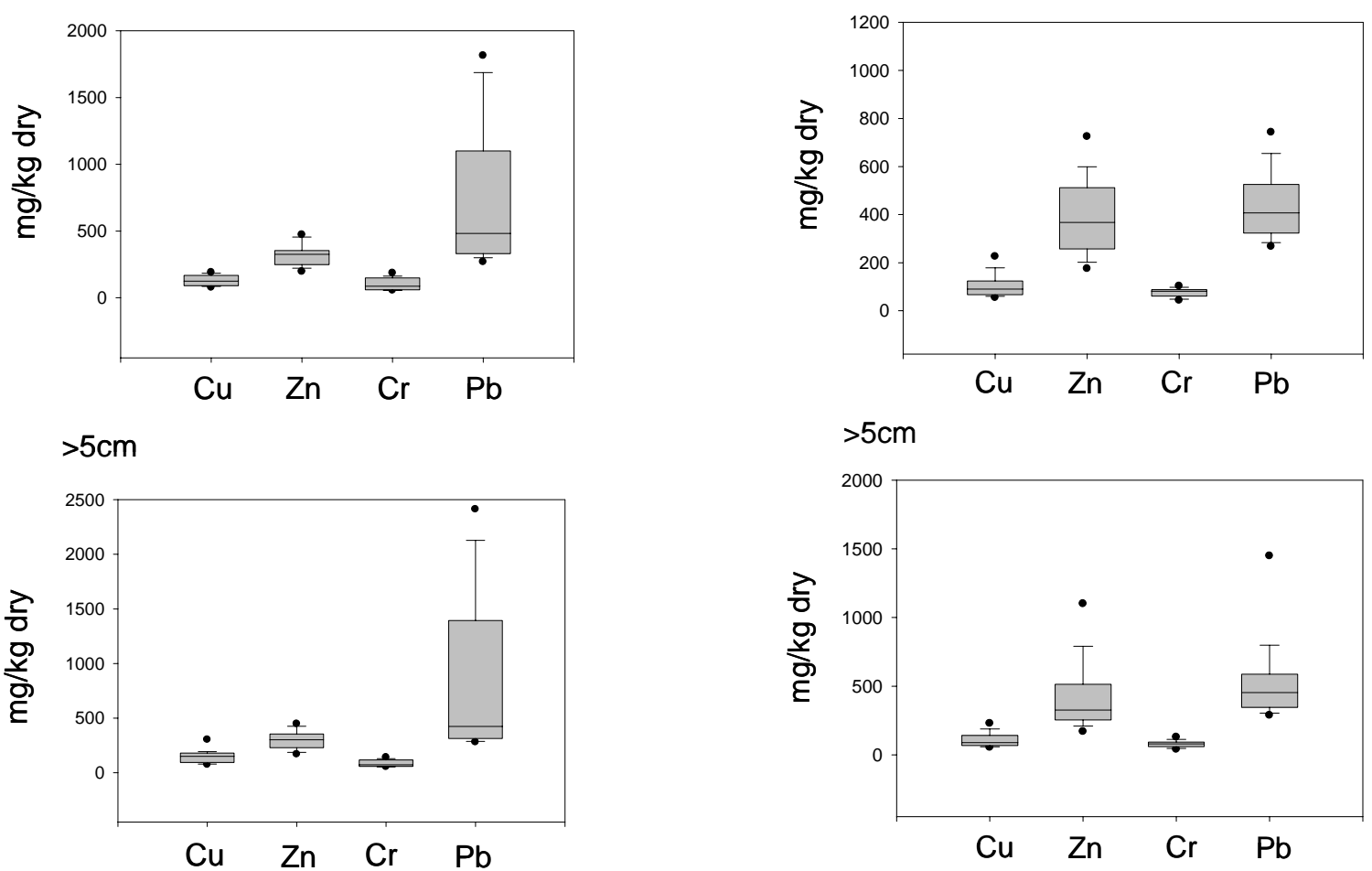

$>5 \mathrm{~cm}$
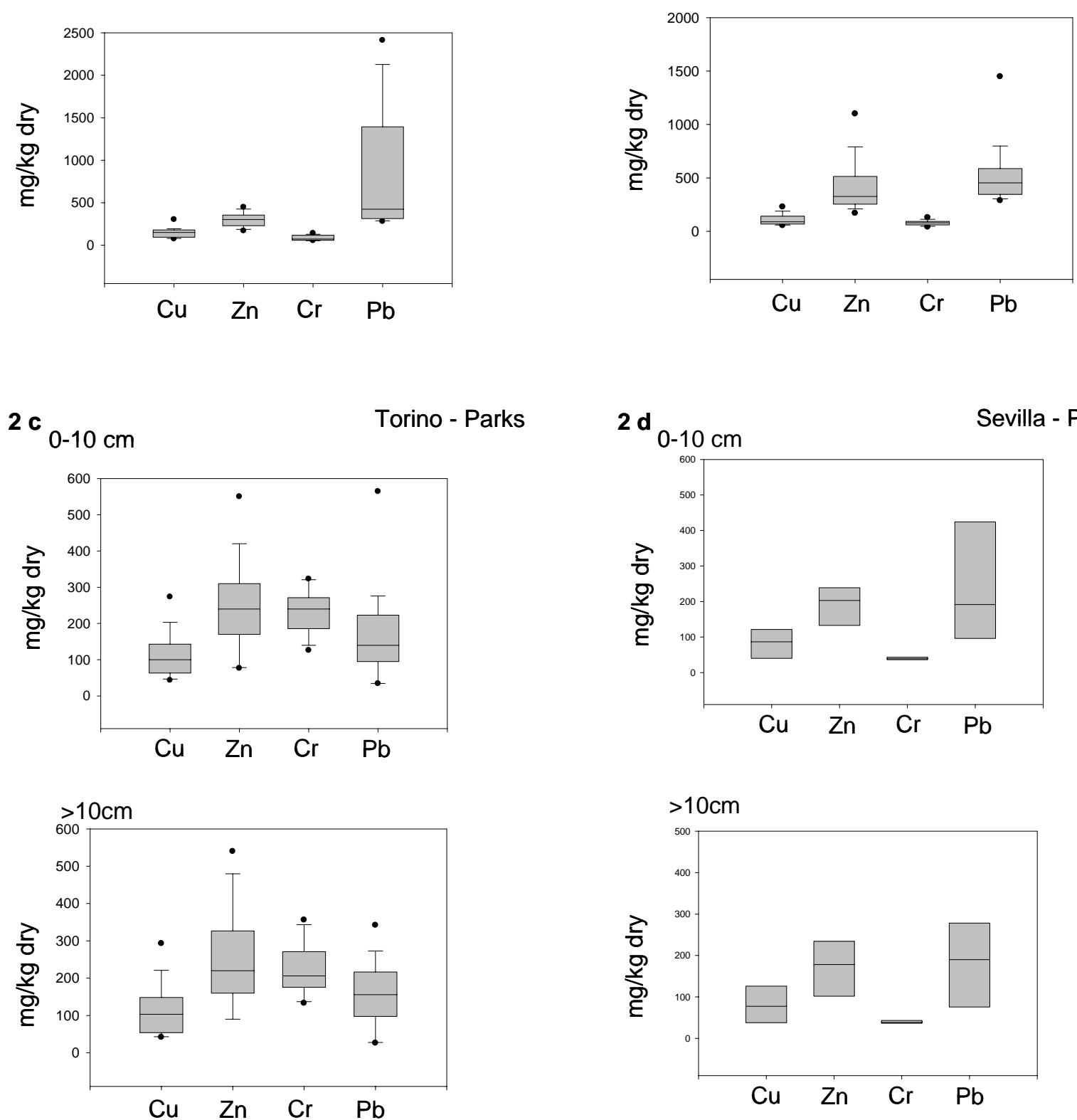

FIGURE 2. BOX PLOTS OF CONCENTRATIONS OF CU, ZN, CR AND PB IN SURFACE AND SUBSURFACE SOILS FROM: (A) PARKS IN GLASGOW; (B) ALLOTMENTS IN GLASGOW; (C) PARKS IN TORINO; AND (D) PARKS IN SEVILLA 
Table 4. Summary of metal content

\begin{tabular}{|c|c|c|c|c|c|c|c|}
\hline & $\begin{array}{c}\mathrm{Fe} \\
\%\end{array}$ & \multicolumn{5}{|c|}{$\mathrm{mg} / \mathbf{k g}$} & $\mathrm{Pb}$ \\
\hline \multicolumn{8}{|l|}{ Sevilla } \\
\hline mean & 2.07 & 491 & 73 & 138 & 22 & 40 & 150 \\
\hline RSD (\%) & 17 & 24 & 133 & 74 & 26 & 27 & 1360 \\
\hline $\max$ & 3.18 & 876 & 698 & 611 & 34 & 64 & 1080 \\
\hline $\min$ & 1.33 & 323 & 14 & 38 & 11 & 18 & 14 \\
\hline $\mathrm{n}$ & 62 & 62 & 62 & 62 & 62 & 62 & 62 \\
\hline \multicolumn{8}{|l|}{ Torino } \\
\hline mean & 3.28 & 947 & 111 & 242 & 193 & 229 & 158 \\
\hline RSD (\%) & 10 & 12 & 57 & 50 & 24 & 27 & 65 \\
\hline $\max$ & 3.84 & 1183 & 293 & 550 & 300 & 356 & 565 \\
\hline $\min$ & 2.38 & 725 & 40 & 75 & 123 & 126 & 17 \\
\hline$n$ & 39 & 40 & 40 & 40 & 24 & 24 & 40 \\
\hline \multicolumn{8}{|l|}{ Glasgow } \\
\hline mean & 3.53 & & 140 & 364 & 58 & 93 & 971 \\
\hline RSD (\%) & 19 & & 58 & 44 & 33 & 40 & 106 \\
\hline $\max$ & 5.96 & & 484 & 1004 & 116 & 217 & 7051 \\
\hline $\min$ & 2.47 & & 52 & 164 & 32 & 40 & 250 \\
\hline$n$ & 62 & & 62 & 62 & 62 & 62 & 62 \\
\hline \multicolumn{8}{|l|}{ Reference values $^{*}$} \\
\hline Italy & - & - & 120 & 150 & 120 & 150 & 100 \\
\hline Andalucía, Spain & - & - & $150-500$ & $300-1000$ & $80-300$ & $250-400$ & $250-500$ \\
\hline UK - ICRCL (gardens) & - & - & 130 & 300 & 70 & 600 & 500 \\
\hline UK - ICRCL (open spaces) & - & - & - & - & - & 1000 & 2000 \\
\hline UK - Minimum CLEA SGV & - & - & - & - & 50 & 130 & 450 \\
\hline
\end{tabular}

* See Ferguson (1999) and http://www.clarinet.at/

specific rural urban transect through the 'central belt' region of Scotland in which Glasgow is located. For all elements reported here, the range (maximum-minimum) is significantly higher than both the data for this national survey and the regional transect, suggesting a significant urban signature in the parks and allotments sampled.

A much more detailed analysis of the samples from Sevilla has already been presented (Madrid et al. 2002), and tends to confirm observations made about the soils sampled in the cities of Torino and Glasgow. In Sevilla, $\mathrm{Cu}, \mathrm{Pb}$ and $\mathrm{Zn}$ are enhanced in parks and gardens, and there is evidence of a relationship of contamination levels with vehicle movement.

Clearly, direct comparison to results from other studies of absolute concentration levels has relatively limited merit in terms of defining good or bad soil quality, or the impact of urban activities on soil metal content. However, it would appear that a common group of metallic pollutants is a signature of the cumulative impact of general urban processes across urban environments, and is worthy of further investigation.
The range of maximum values would appear to present a challenge to urban managers when compared to 'guideline' values for the regulatory regime in each region, given the complexity of the EU dimension to soil contamination (Ferguson 1999). The values at the foot of Table 4, indicate a significant degree of overlap with the results of this study, even in the case of a city where the natural background is high.

Figure $2(\mathrm{a}-\mathrm{d})$ presents box plots to show the variability of data for surface and sub-surface soil samples from each city. In the case of Glasgow, the samples have been separated into park and allotment data-sets. The variation in metal content within the individual cities is relatively high, with $\mathrm{Pb}$ and $\mathrm{Zn}$ dominating the patterns in all three cases. The relative scale of variation is different between Glasgow and the other two locations (note axes), but, in all cases, the plots show little difference between the surface and subsurface soils. In the case of Sevilla, the data show no outliers, which are seen for Glasgow and Torino. For the allotment sites in Glasgow, the pattern is similar, with $\mathrm{Zn}$ 

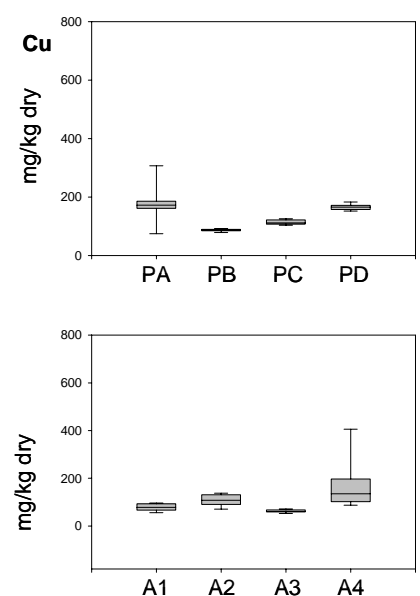

$3 b$
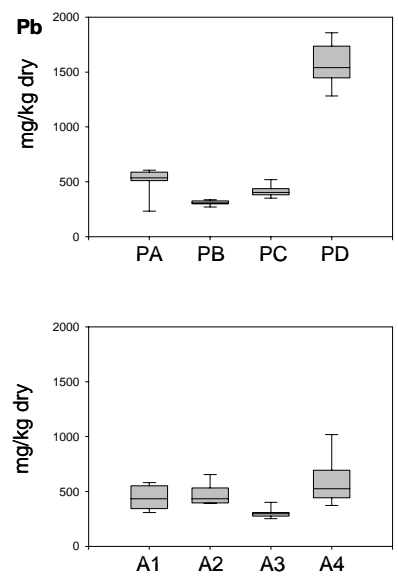
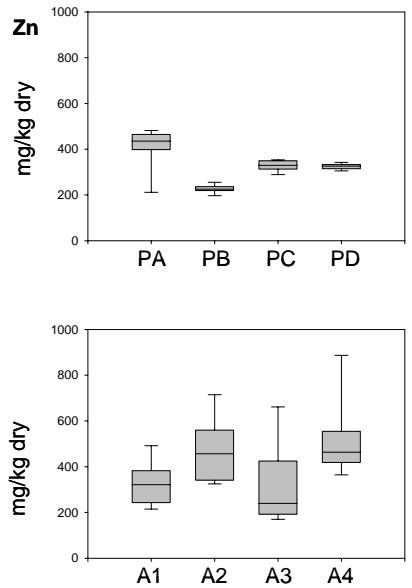

FIGURE 3. BOX PLOTS TO SHOW WITHIN-SITE VARIABILITY FOR (A) CU, (B) PB AND (C) ZN IN THE FOUR PARK AND FOUR ALLOTMENT SITES IN GLASGOW

and $\mathrm{Pb}$ dominating; however, the values show less variation, particularly in the case of $\mathrm{Pb}$.

In Figure 3, the within-site variations for some of the Glasgow soil metal data $(\mathrm{Cu}, \mathrm{Pb}$ and $\mathrm{Zn})$ are presented for the four park and allotment locations. Plots for $\mathrm{Ni}$ and $\mathrm{Cr}$ are not included, as the variability is low and little difference was observed between the two different land uses. All data for each metal in surface and sub-surface samples have been pooled. For the park locations, the variation is relatively low, except for $\mathrm{Pb}$ in one site and to a lesser extent $\mathrm{Zn}$ at another location. Clearly, there is much more variability in the allotment data, which may reflect differences in sampling approach (Table 2). However, this cannot explain the element-to-element variation between sites, and thus emphasises the impact of soil use on metal content.

\section{CONCLUSIONS}

This pilot assessment of metal distribution in public parks from three cities in Europe, has highlighted the diverse range of concentrations and the contribution from anthropogenic and natural sources. It has provided a context for future consideration of soil quality in urban environments.

The differences in environmental setting for each of the study locations influence basic soil properties and, consequently, will impact on the relative availability of the metals. From the limited sample-set, the relative variability in metal content between cities seems surprisingly low, when obvious outliers are removed. However, the presence of locations with enhanced levels of, in particular, $\mathrm{Pb}$ and $\mathrm{Zn}$, from locations which have remained relatively undisturbed over extended periods, points to significant potential contributions from diffuse pollution sources over time.

This has obvious implications for the management of the sites and, as discussed widely elsewhere, challenges the strategy for guideline limits/values in managing soil resources. Clearly, some locations would be considered to be in need of more detailed risk assessment/remediation.

The impact of differing land use within the Glasgow sites, as reflected in parkland versus allotment use, again suggests different scales of variability. This would be expected from the contrasting soil turnover/ amendment from active agricultural use. It also highlights the potential significance of inter-allotment differences, and the question of different sources of metal.

Clearly, this pilot study has limitations in the description of processes and factors influencing soil metal content. However, it has established a baseline data-set, with the scale of variation in metal content assessed across similar land use types upon which a more detailed investigation has been based. At the time of writing (March 2004), the URBSOIL project is progressing, with a comprehensive assessment of urban soil collected from public open spaces in six cities across the EU. This will include data from approximately 150 locations per city, and information about metal bioavailability, organic contaminants, and largescale soil processes. The soil quality attributes of the material assessed on the basis of contaminant content and availability, and basic soil properties, will form a harmonised data-set describing the urban soil resource. This will be integrated within a decision-support framework, which will allow exploration of the complex context of sustainable urban management. 


\section{ACKNOWLEDGEMENTS}

We would like to thank Mr Michal Bialowski, Mr Konrad Swiderski and Mr David Stirling for help with the sampling and analysis of the Glasgow samples.

\section{REFERENCES}

Birke, M. and Rauch, U. (2000) Urban geochemistry: Investigations in the Berlin metropolitan area. Environmental Geochemistry \& Health, 22, 233-248

Bullock, P. and Gregory, P.J. (1991) (eds.) Soils in the Urban Environment. Blackwell, Oxford, UK

Chen, T.B., Wong, J.W.C., Zhou, H.Y. and Wong, H.M. (1997) Assessment of trace metal distribution and contamination in surface soils of Hong Kong. Environmental Pollution, 96, 61-68

Effland, W.R. and Pouyat, R.V. (1997) The genesis, classification, and mapping of soils in urban areas. Urban Ecosystems, 1, 217-228

Facchinelli, A., Sacchi, E. and Mallen, L. (2001) Multivariate statistical and GIS-based approach to identify heavy metal sources in soils. Environmental Pollution, 114, 313324

Ferguson, C. (1999) Assessing risks from contaminated sites: policy and practice in 16 European countries. Land Contamination and Reclamation, 7 (2), 33-54

Gee, G.W. and Bauder, J.W. (1986) Particle size analysis. In: Klute, A. (ed.) Methods of Soil Analysis. Part I. Physical and Mineralogical Methods. Agronomy Series no. 9. American Society of Agronomy, Madison, WI

HMSO (1986) The Analysis of Agricultural Materials, 3rd ed. MAFF-ADAS, HMSO, London

Imperato, M., Adamo, P., Naimo, D., Arienzo, M., Stanzione, D. and Violante, P. (2003) Spatial distribution of heavy metals in urban soils of Naples city (Italy). Environmental Pollution, 124, 247-256

Jim, C.Y. (1998) Physical and chemical properties of a Hong Kong roadside soil in relation to urban tree growth. Urban Ecosystems, 2, 171-181

Kelly, J., Thornton, I. and Simpson, P.R. (1996) Urban geochemistry: a study of the influence of anthropogenic activity on the heavy metal content of soils in traditionally industrial and non-industrial areas of Britain. Applied Geochemistry, 11, 363-370

Lyons, J.R. (1997) Urban ecosystems management: bringing science and policy together. Urban Ecosystems, 1, 77-83
Madrid, L., Diaz-Barientos, E. and Madrid, F. (2002) Distribution of heavy metal content of urban soils in parks of Seville. Chemosphere, 49, 1301-1308

Manta, D.S., Angelone, M., Bellanca, A., Neri, R. and Sprovieri, M. (2002) Heavy metals in urban soils: a case study from the city of Palermo (Sicily). Science of the Total Environment, 300, 229-243

Page, A.L., Miller, R.H. and Keeney, D.R. (eds.) (1982) Methods of Soil Analysis. Part II. Chemical and Microbiological Properties. Agronomy Series no. 9. American Society of Agronomy, Madison, WI

Pacione, M. (2003) Urban environmental quality and human well-being - a social geographical perspective. Landscape and Urban Planning, 65, 19-30

Paterson, E., Sanka, M. and Clark, L. (1996) Urban soils as pollutant sinks - a case study from Aberdeen, Scotland. Applied Geochemistry, 11, 129-131

Paterson, E., Towers, W., Bacon, J.R. and Jones, M. (2003) Background Levels of Contaminants in Scottish Soils. Report commissioned by the Scottish Environment Protection Agency. Published by MRCS Limited: Registered Office: Cunningham Building, Craigiebuckler, Aberdeen AB15 $8 \mathrm{QH}$

Peltola, P. and Astrom, M. (2003) Urban geochemistry: a multimedia and multielement survey of a small town in northern Europe. Environmental Geochemistry \& Health, 25, 397-419

Pichtel, J., Sawyer, H.T. and Czarnowska, K. (1997) Spatial and temporal distribution of metals in soils in Warsaw, Poland. Environmental Pollution, 98, 169-174

Pickett, S.T.A., Burch, W.R. and Dalton, S.E. (1997) Integrated urban ecosystem research. Urban Ecosystems, 1, 183184

Pickett, S.T.A., Cadenasso, M.L., Grove, J.M., Nilon, C.H., Pouyat, R.V., Zipperer, W.C. and Costanza, R. (2001) Urban ecological systems: linking terrestrial ecological, physical and socio-economic components of metropolitan areas. Ann. Rev. Ecol. Syst., 32, 127-157

Rowell, D.L. (1994) Soil Science: Methods \& Applications. Longman, New York

Van Kamp, I., Leidelmeijer, K., Marsman, G. and de Hollander, A. (2003) Urban environmental quality and human well-being towards a conceptual framework and demarcation of concepts: a literature study. Landscape and Urban Planning, 65, 5-18 
Apart from fair dealing for the purposes of research or private study, or criticism or review, this publication may not be reproduced, stored in a retrieval system or transmitted in any form or by any means, electronic, mechanical, photographic or otherwise, without the prior permission in writing of the publisher.

The views expressed in this article and in all articles published in the journal Land Contamination \& Reclamation are those of the authors alone and do not necessarily reflect those of the editor, editorial board or publisher, or of the authors' employers or organizations with which they are associated. The information in this article is intended as general guidance only; it is not comprehensive and does not constitute professional advice. Readers are advised to verify any information obtained from this article, and to seek professional advice as appropriate. The publisher does not endorse claims made for processes and products, and does not, to the extent permitted by law, make any warranty, express or implied, in relation to this article, including but not limited to completeness, accuracy, quality and fitness for a particular purpose, or assume any responsibility for damage or loss caused to persons or property as a result of the use of information in this article. 